\title{
EFFECT OF IRRIGATION WITH SALINE WATER ON SOIL AND CROP IN SOUTH-WEST SPAIN
}

\author{
M.M.RIDAO, F. MORENO, F. CABRERA, J.E. FERNANDEZ and M.J. PALOMO \\ Instituto de Recursos Naturales y Agrobiologia de Sevilla (IRNAS, CSIC), Seville, \\ Spain
}

E. FERNANDEZ-BOY

Department of Agricultural Chemistry, University of Seville, Seville, Spain.

\section{Abstract}

The drained and irrigated marshes of the Guadalquivir river (SW Spain) are formed on soils of high clay content (about $70 \%$ ), high salinity, and a shallow, extremely saline, water table. Irrigation is necessary for successful crop production in this region of low and variable rainfall. In some years, however, water supply for irrigation is limited due to drought periods, and farmers are obliged to irrigate with river water, which at this location is of high salinity due to tidal flow. The objective of this work was to evaluate the effects of irrigation with water of high salinity on soil properties and growth and yield of cotton crop. The experiments were carried out during 1997. Irrigation was applied by furrows. Water content profile, tensiometric profile, water table level, drainage water flow, soil salinity, leaf water potential, stomatal conductance, and crop development and crop yield were monitored. The results showed that after the irrigation with saline water, the soil salinity increased. This increase was more noticeable in the top layer $(0-30 \mathrm{~cm}$ depth). After five irrigations with water of good quality, the salinity of the soil in the subplot irrigated with saline water reached values similar to those before the application of saline water. The irrigation with saline water affected crop development. Despite the negative effects on crop development and water status in plants, the crop yield was the same as on the subplot irrigated with nonsaline water.

Keywords: Crop development, drainage, furrow irrigation, saline water, soil salinity.

\section{Introduction}

In semiarid and arid areas water is a limiting factor for the sustainability of irrigated agriculture, and the use of water of low quality is also a risk for the environment. The

Water and the Environment: Innovative Issues in Irrigation and Drainage. Edited by Luis S. Pereira and John W. Gowing. Published in 1998 by E \& FN Spon. ISBN 0419237100 
Guadalquivir river marshes in south-west Spain cover an area of 140000 ha. They were formed by the accumulation of fine material dragged by the river into the large estuary excavated in the Diluvial Era. The sediments, originated from Miocene and Triassic formations in the medium and high river basin, are mainly calcareous marls, with some chalk marls. The materials forming the Guadalquivir marshes are typical of sediments deposited at different levels. The most recent sediments, $0-2 \mathrm{~m}$ thick, were deposited on the lower parts, in depressions with water-logging or run-off phenomena, enriched with salts by evaporation. In most cases, soils developed in this area are of clayey nature (about $70 \%$ clay content), mainly illite type with a very advanced degree of alteration [1]. They are difficult to manage in agriculture due to their high clay and salt contents [2] and to the presence of a shallow, very saline water table.

In this region of low and variable rainfall, irrigation of these soils is necessary for successful crop growth. Drainage is also required to ensure that the highly saline water table does not encroach into the root zone. In some years, however, water supply for irrigation is limited due to drought. The scarcity of good quality water during the drought period 1993-1995 imposed on farmers the necessity to irrigate with river water, which at this location is of high salinity due to tidal flow.

The objective of this work was to evaluate the effects of irrigation with water of high salinity on soil properties and growth and yield of cotton crop. The results provide data for the management of irrigation with saline water and for sustainability of agriculture in periods of water scarcity in the area.

\section{Materials and Methods}

Experiments were carried out during 1997 in a farm plot of 12.5 ha $(250 \mathrm{~m} \times 500 \mathrm{~m})$ situated in an area of marshes on the left bank of the Guadalquivir river, near Lebrija (south-west Spain). The soil of the plot is of clayey texture and its general characteristics are given in Table 1. The mineralogical composition of the clay fraction ( $70 \%$ altered illite; $15 \%$ smectite; $10 \%$ kaolinite; < $1 \%$ interstratified) is very homogeneous throughout the profile. The plot has been installed with a drainage system, consisting of cylindrical ceramic sections ( $30 \mathrm{~cm}$ long) forming pipes $250 \mathrm{~m}$ long, buried at a depth of $1 \mathrm{~m}$ and spaced at intervals of $10 \mathrm{~m}$. These drains discharge into a collecting channel perpendicular to the drains. This drainage system controls the water table level, which remains at a depth of approximately $0.9 \mathrm{~m}$. The electrical conductivity (EC) of the water table is $>80 \mathrm{dS} \mathrm{m}-1$. It is imperative that this water table does not encroach into the root zone, hence irrigation must be complemented by drainage.

Two subplots of 0.5 ha $(20 \mathrm{~m} \times 250 \mathrm{~m})$ each were selected. Cotton was growing on both subplots, and irrigation was applied by furrows. Cotton was sown on February 23,

Table 1. General characteristics of the soil

\begin{tabular}{llllll}
\hline Depth $(\mathrm{cm})$ & \multicolumn{3}{l}{ Soil particle size $(\% \mathrm{w} / \mathrm{w} \mu \mathrm{m})$} & $\mathrm{CaCO}_{3}(\%)$ & O.M. (\%) \\
\cline { 2 - 5 } & $>50$ & $50-2$ & $<2$ & & \\
\hline $0-30$ & 1.0 & 32.0 & 67.0 & 16.0 & 1.03 \\
$30-60$ & 1.0 & 30.0 & 69.0 & 16.0 & - \\
$60-90$ & 1.0 & 30.0 & 69.0 & 19.0 & - \\
\hline
\end{tabular}


1997 , and mulched with plastic film. One subplot was irrigated with good quality water $\left(E C=0.89 \mathrm{dS} \mathrm{m}^{-1}\right)$ during the whole season, while in the other subplot one of the irrigations (on 7 July 1997 at flowering stage) was with water of high salinity (EC = $22.7 \mathrm{dS} \mathrm{m}^{-1}$ ). The saline water used for irrigation was taken from the collecting channels. The amount of water applied in each irrigation was $60 \mathrm{~mm}$.

Four measurement sites were situated within each subplot, at which the water content profile, tensiometric profile, water table level, and salinity of soil were monitored. The drainage water discharge flow was also measured and the salinity of water analysed periodically.

A neutron probe was used to measure water content in the soil. Mercury tensiometers were used to measure the water tension at different depths. Drainage water flow was measured by means of a limnigraph with a $V$-notch weir. Soil samples $(0-30,30-60$ and $60-90 \mathrm{~cm}$ depth) were taken periodically at the four sampling sites.

Electrical conductivity (EC), alkalinity (Alk.), $\mathrm{Cl}^{-}, \mathrm{SO}_{4}{ }^{2}, \mathrm{Na}^{+}, \mathrm{K}^{+}, \mathrm{Ca}^{2+}$ and $\mathrm{Mg}^{2+}$ were determined in water samples, and in saturated paste extracts.

Plant height and leaf area index (LAI) were measured at several dates during the growing season. Leaf water potential was measured with a pressure chamber (Soilmoisture Equipment Corp., Santa Bárbara, California, USA), and measuremets of stomatal conductance were made with a steady-state porometer (LI-1600, LICOR) in leaves, which were sunny and healthy, of six plants in each subplot.

\section{Results and Discussions}

Figure I shows the drain outflow hydrographs corresponding to the irrigation on 7 July 1997. These results clearly show no differences between the drainage behaviour in the subplot irrigated with non-saline water and subplot irrigated with saline water. Similar results were obtained in the next irrigations. These hydrographs show the same pattern as those described in previous experiments with furrow irrigation in this area [3]. The drain discharge started between $30 \mathrm{~min}$ and one hour after the beginning of irrigation, which also agrees with the results of Moreno et al. [3].

Changes in $E C_{\mathrm{sp}}$ of the saturated paste extract of soil samples, taken on various dates after the irrigation on 7 July 1997, are shown in Fig. 2. In the subplot irrigated with saline water, the $\mathrm{EC}_{\mathrm{sp}}$ increased immediately after irrigation in both soil layers $(0-30 \mathrm{~cm}$ and $30-60 \mathrm{~cm}$ depths). In the top layer $(0-30 \mathrm{~cm})$, the $\mathrm{EC}_{\mathrm{sp}}$ started to decrease after the first irrigation with non-saline water, and reached similar values to those before the irrigation with saline water. In contrast, the decrease of $\mathrm{EC}_{\mathrm{sp}}$ in the $30-60 \mathrm{~cm}$ layer was lower than in the top layer. Significant differences $(P<0.05)$ between the $\mathrm{EC}_{\mathrm{sp}}$ of the two subplots for the $0-30 \mathrm{~cm}$ layer were found only for the period between the irrigation with saline water and the sampling date after the last irrigation with normal water. For the $30-60 \mathrm{~cm}$ layer, significant differences were maintained till the end of the growing season, and even after the rainy period.

Figure 3 shows the increase of soluble $\mathrm{Na}_{\mathrm{sp}}$ in the subplot irrigated with saline water. The change of $\mathrm{Na}_{\mathrm{sp}}$ in both soil layers follows a similar pattern to that of the electrical conductivity. Differences in $\mathrm{Na}_{\mathrm{sp}}$ between the two soil layers were significant $(\mathrm{P}<0.05)$ from 15 July 1997 till the end of the growing season, and also after the rainy period. 


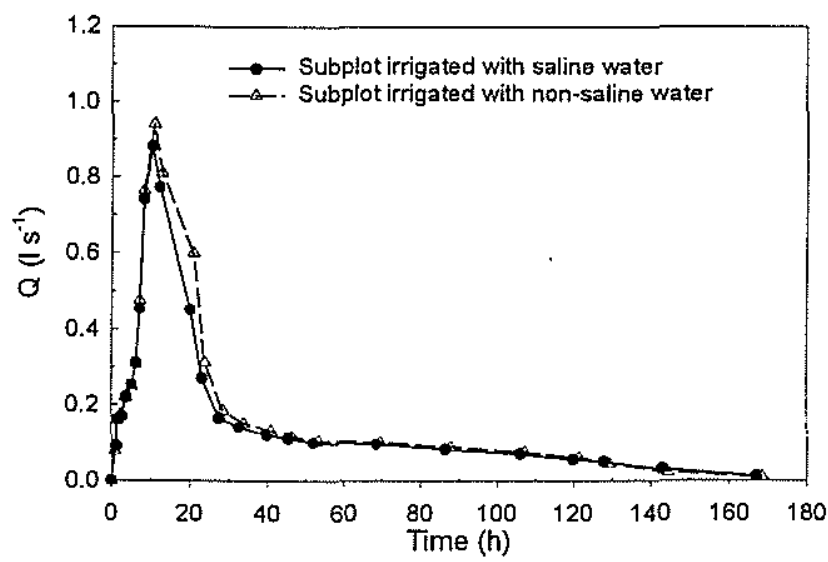

Fig. 1. Drain outflow (Q) hydrographs after irrigation on 7 July 1997 in both subplots

On 16 January 1998, $\mathrm{Na}_{\text {sp }}$ values were significantly different between the subplot irrigated with saline water and the subplot irrigated with non-saline water at both depths, but these values are of the same order as those reported by Cabrera et al. [4] and Moreno et al. [3] for the same commercial plot. As in the case of $\mathrm{EC}_{\mathrm{sp}}$, the soluble sodium concentration in the saturated paste extract decreased after irrigation with nonsaline water, and tended to reach similar values to those before the irrigation with saline water. The pattern of sodium adsorption rate (SAR) was similar to that of $\mathrm{Na}_{\text {sp }}$ in both soil layers (data not shown). Significant differences in SAR were observed between the two soil layers. At the end of the rainy period, significant differences in SAR were maintained between the soil of the subplot irrigated with saline water and the subplot irrigated with normal water. SAR values of both subplots are similar to those reported by Moreno et al. [3] for the soil of the same commercial plot under cotton crop irrigated by furrow with non-saline water.

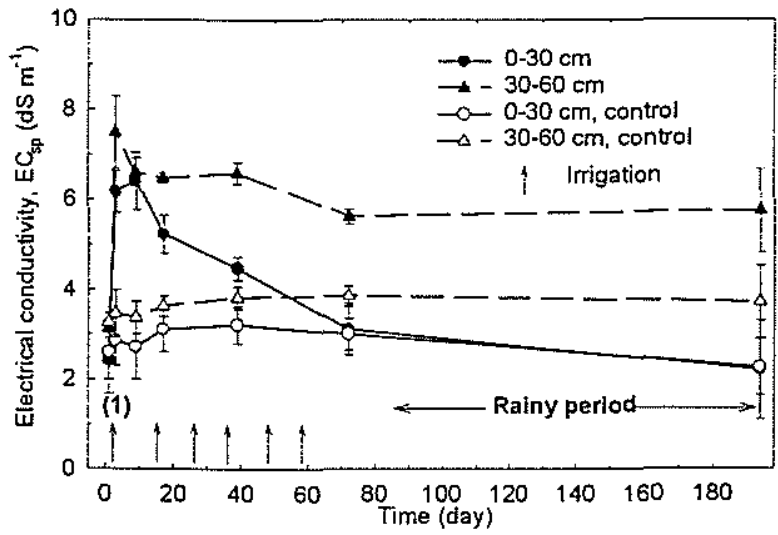

Fig. 2. Change of electrical conductivity of the saturated paste extracts $\left(E C_{\mathrm{sp}}\right)$ after irrigation on 7 July 1997 in subplot irrigated with saline water (filled symbols) and in subplot irrigated with non-saline water (empty symbols). (l) date of application of saline water. (Vertical bars are standard errors) 


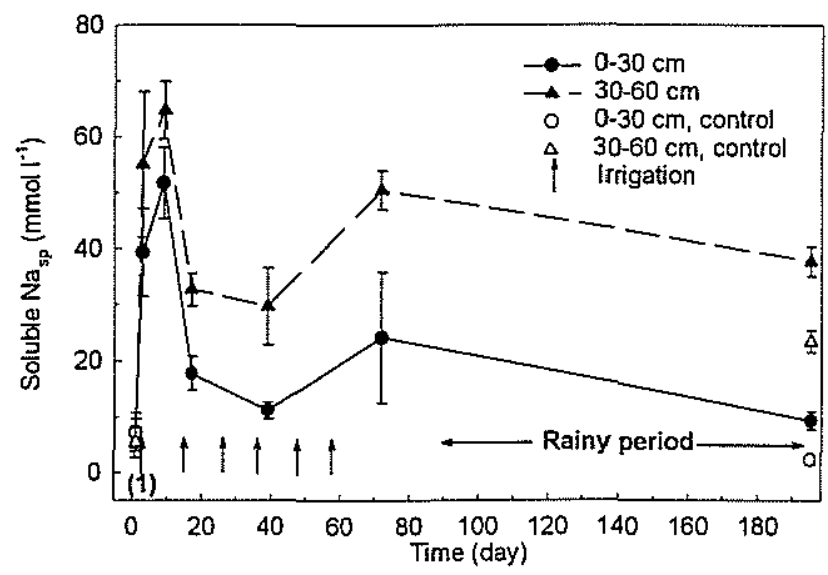

Fig. 3. Change of concentration of soluble sodium in the saturated paste extracts $\left(\mathrm{Na}_{\mathrm{sp}}\right)$ after irrigation on 7 July 1997 in the subplot irrigated with saline water (filled symbols) and in the subplot irrigated with non-saline water (empty symbols). (1) date of application of saline water. (Vertical bars are standard errors).

Higher $\mathrm{Na}_{\mathrm{sp}}$ and $\mathrm{SAR}$ values, after the rainy period (the total amount of rain was 480 $\mathrm{mm}$ ), in the subplot irrigated with saline water than in the subplot irrigated with nonsaline water seem to indicate that leaching was less effective in the former. However, as mentioned above, these values are similar to those found in these soils under irrigation with non-saline water, and do not represent a serious problem for the next crop.

Soil water potential at a depth of $40 \mathrm{~cm}$ was lower in the subplot irrigated with saline water than in the subplot irrigated with non-saline water during the period between 9 July 1997 and 14 August 1997. However, the differences were not significant $(\mathrm{P}<$ 0.05 ).

Changes of soil water content profile (Fig. 4) were similar in both subplots. This,
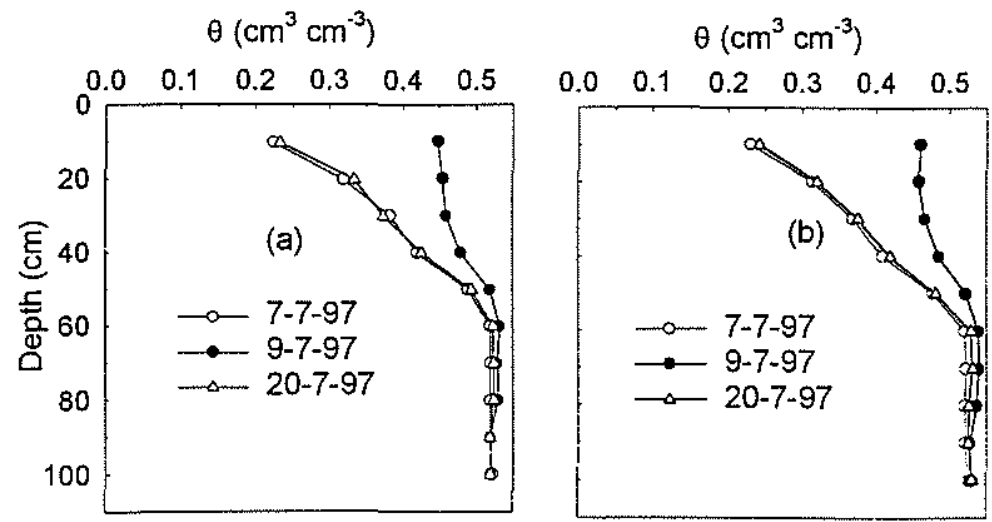

Fig. 4. Soil water content profiles before and after irrigation on 7 July 1997: (a) subplot irrigated with non-saline water; (b) subplot irrigated with saline water. 

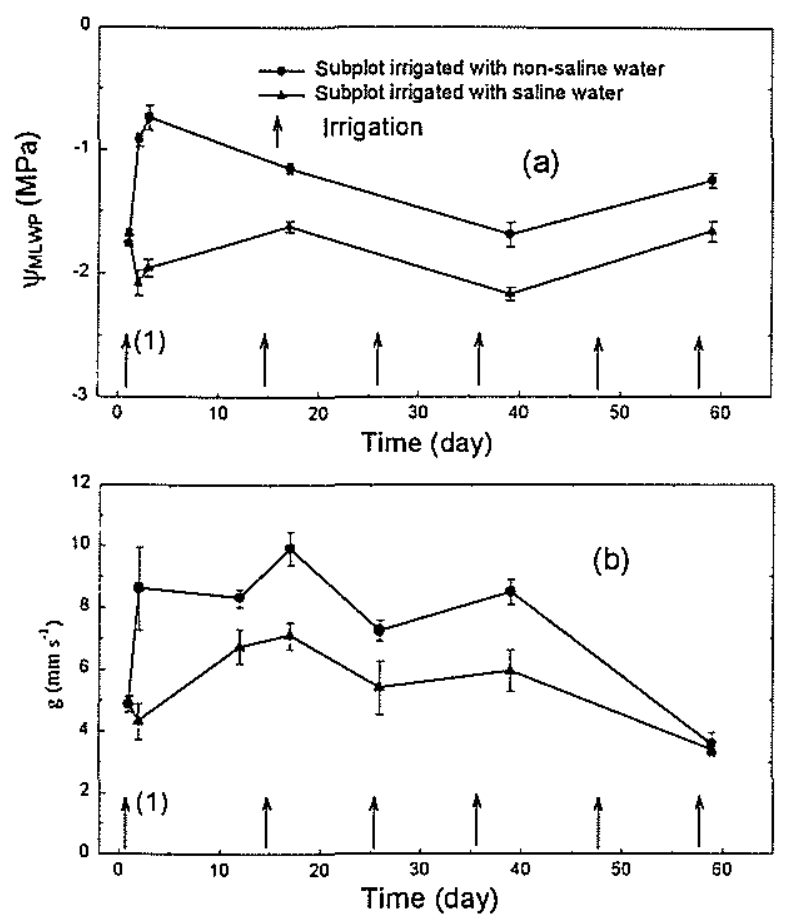

Fig. 5. Change of (a) the midday leaf water potential ( $\Psi_{\mathrm{MLWP}}$ ) and (b) stomatal conductance g, after irrigation on 7 July 1997 in the tow subplots. ). (1) date of application of saline water. (Vertical bars are standard errors).

together with a similar drainage behaviour, seems to indicate that a single application of this very saline water did not affect the physical properties of the soil.

The irrigation on 7 July 1997 with saline water affected the crop development. Results of plant height and LAI (Table 2) show that a few days before the irrigation with saline water, plant height and LAI were practically the same in both subplots. On 27 July 1997, the plants of the subplot that received the application of saline water showed significantly lower plant height than the subplot irrigated with non-saline water. $\mathrm{LAI}$ value was also significantly lower. It seems that the saline water produced a severe stress and consequently reduced the crop development. Fig. 5 shows results of midday leaf water potential ( $\psi_{\text {ML.WP }}$ ) and stomatal conductance $(\mathrm{g})$ in both subplots. Before application of saline water (on 7 July 1997) $\psi_{\mathrm{ML} \text { WP }}$ and g were practically the same in the two subplots. After this application $\psi_{\mathrm{ML} W \mathrm{~W}}$ and $\mathrm{g}$ were significantly lower in the subplot irrigated with saline water than in the subplot irrigated with non-saline water as reported by other authors, [5]. In contrast, fruit development was accelerated in these plants. The yield was slightly (but not significantly) higher than in the subplot irrigated with non-saline water (Table2). These results seem to indicate an increase in the water use efficiency by the crop irrigated with saline water. 
Table 2. Plant height, leaf area index (LAI) and yield in the two subplots.

\begin{tabular}{|c|c|c|c|c|c|}
\hline \multirow[t]{2}{*}{ Subplot } & \multicolumn{2}{|c|}{ Plant height $(\mathrm{cm})$} & \multicolumn{2}{|l|}{ LAI } & \multirow[t]{2}{*}{ Yield $\left(\mathrm{kg} \mathrm{ha}^{-1}\right)$} \\
\hline & $3-7-97$ & $27-7-97$ & $3-7-97$ & $27-7-97$ & \\
\hline $\begin{array}{l}\text { Irrigated with } \\
\text { saline water on } \\
7-7-97\end{array}$ & $64.4 \mathrm{a}$ & $69.7 \mathrm{a}$ & $3.50 \mathrm{a}$ & $3.71 \mathrm{a}$ & 4303 a \\
\hline $\begin{array}{l}\text { Irrigated with } \\
\text { Non-saline } \\
\text { water }\end{array}$ & $63.5 \mathrm{a}$ & $101.5 \mathrm{~b}$ & $3.68 \mathrm{a}$ & $4.86 \mathrm{~b}$ & $4160 a$ \\
\hline
\end{tabular}

Values in the same column followed by the same letter are not significantly different $(P<0.05)$.

\section{Conclusions}

Results presented in this paper clearly show that the use of water of high salinity for irrigation in the reclaimed salt-affected soils of the Guadalquivir marshes increases the electrical conductivity, soluble sodium, and sodium adsorption rate of the soil profile. After several irrigations with non-saline water these parameters decreased to values similar to those before the irrigation with saline water.

The $\mathrm{EC}_{\mathrm{sp}}$ reached a maximum value of $7.5 \mathrm{dS} \mathrm{m}^{-1}$ during the period between the application of saline water and the next irrigation with normal water. This $\mathrm{EC}_{\mathrm{sp}}$ value was slightly lower than the $\mathrm{EC}_{\mathrm{sp}}$ threshold $\left(7.7 \mathrm{dS} \mathrm{m}^{-1}\right)$ given for cotton crop. The application of one irrigation with saline water negatively affected crop development. In contrast, yield was not affected.

These results indicate that it is possible to use saline water for supplementary irrigation in this area during years when the amount of of good quality water is limited, without serious problems for soil and crop.

\section{Acknowledgements}

The authors wish to thank J. Rodriguez and J.P. Calero for help with measurements in the field. This study was supported with funds of the Spanish CICYT, project HID961292, and the Junta de Andalucia (Research Group AGR-151).

\section{References}

1. Moreno, F., Arrue, J.L., Murillo, J.M., Pérez, J.L. and Martín, J., 1980. Mineralogical composition of clay fraction in marsh soils of SW Spain. Polish Journal of Soil Scicience, Vol. 13. pp. 65-72.

2. Moreno, F., Martín, J. and Mudarra, J.L., 1981. A soil sequence in the natural and reclaimed marshes of the Guadalquivir river, Seville (Spain). Catena, Vol. 8. pp. 201-221.

3. Moreno, F., Cabrera, F., Andreu, L., Vaz, R., Martin-Aranda, J. and Vachaud, G., 1995. Water movement and salt leaching in drained and irrigated marsh soils 
of southwest Spain. Agricultural Water Management, Vol. 27. pp. 25-44.

4. Cabrera, F., Vaz, R, Rieu, M. and Gaudet, J.P., 1992. Irrigation in a reclaimed salt affected soil of southwest Spain: II. Chemical properties. In: Proceedings of the International Symposium on Strategies for Utilizing Salt Affected Lands, Bangkok, Thailand. pp. 179-189.

5. Henggeler, J. and Moore, J. (1995) The effect of salinity on cotton. In: Proceedings Beltwide Cotton Conferences, San Diego, CA. National Cotton Council of America, Memphis, TN, USA. pp. 1134-1136. 